\title{
Anchored palladium bipyridyl complex in nanosized MCM-41: a recyclable and efficient catalyst for the Kumada-Corriu reaction
}

\author{
Fu-Yu Tsai, ${ }^{\mathrm{a}, *}$ Bo-Nan Lin, ${ }^{\mathrm{a}}$ Ming-Jie Chen, ${ }^{\mathrm{a}}$ Chung-Yuan Mou ${ }^{\mathrm{b}}$ and Shiuh-Tzung Liu ${ }^{\mathrm{b}}$ \\ anstitute of Organic and Polymeric Materials, National Taipei University of Technology, Taipei 106, Taiwan \\ ${ }^{\mathrm{b}}$ Department of Chemistry, National Taiwan University, Taipei 106, Taiwan
}

Received 15 December 2006; revised 5 March 2007; accepted 7 March 2007

Available online 12 March 2007

\begin{abstract}
A palladium bipyridyl complex anchored onto nanosized mesoporous silica MCM-41 catalyzed the cross-coupling of aryl iodides or bromides with Grignard reagents to provide the corresponding biaryls in high yields. The reaction proceeded smoothly with an equal molar amount of substrate and Grignard reagent in the presence of $0.2-0.02 \mathrm{~mol} \%$ of catalyst in $\mathrm{THF}$ at $50{ }^{\circ} \mathrm{C}$ or under refluxing conditions. The catalyst prepared may be used in a very low percentage, recovered after reaction, and re-used.
\end{abstract}

(C) 2007 Elsevier Ltd. All rights reserved.

\section{Introduction}

Transition metal-catalyzed cross-coupling of carbon-carbon bonds is one of the most powerful tool in organic synthesis. ${ }^{1}$ Among these reactions, the use of nickel and palladium complexes for the coupling of aryl halides and Grignard reagents is known as the Kumada-Corriu reaction, ${ }^{2,3}$ which provides a direct and efficient method for the formation of substituted aromatic compounds in industrial processes. ${ }^{4}$ In recent years, the development of the catalysts, particularly those recyclable for this reaction has received much attention due to their industrial applications. In this context, the immobilization of metal complexes onto solid supports to develop heterogeneous catalysts with high activities and selectivities appears to be an interesting approach. For example, Lipshutz and co-workers have reported $\mathrm{C}-\mathrm{C}$ coupling reactions using $\mathrm{Ni} / \mathrm{C}$ as a catalyst, ${ }^{5}$ whereas Styring and co-workers have demonstrated that salen-type Ni(II) complexes immobilized onto a Merrifield resin appears to be a good recyclable catalyst. ${ }^{6}$ Furthermore, salen-type Ni(II) complexes on functionalized silica gel can be applied in a mini-continuous flow system or in a batch reactor. ${ }^{7}$

Ordered mesoporous silica materials such as MCM-41 and SBA-15 have been widely used as supports for various

Keywords: Recyclable catalyst; Kumada-Corriu reaction; Mesoporous silica; Palladium bipyridyl complex.

* Corresponding author. Fax: +886 22731 7174; e-mail: fuyutsai@ntut. edu.tw catalysts because of their high surface area, tunable and uniform pore size, facile separation from reaction mixtures and easily recyclable nature. A desirable approach is to immobilize a homogeneous catalyst on such mesoporous materials without losing its activity. ${ }^{8}$ Supported homogeneous catalysts can offer the selectivity of homogeneous catalysts and the easy separation of heterogeneous catalysts. To date, several palladium complexes have been tethered on MCM-41 for use as catalysts in organic reactions, such as the Heck reaction, ${ }^{9}$ Suzuki reaction, ${ }^{10}$ hydrocarboxylation, ${ }^{11}$ hydrogenation, ${ }^{12}$ azide reduction, ${ }^{13}$ Sonogashira coupling ${ }^{14}$ and indole formation. ${ }^{15}$ However, there have been no previous reports on the immobilization of palladium complexes on ordered mesoporous supports for use in the KumadaCorriu reaction. Recently, we reported the preparation of palladium bipyridyl complex grafted onto nanosized mesoporous silica (denoted as NS-MCM-41-Pd, Fig. 1) and showed its excellent activity as well as recyclability in the

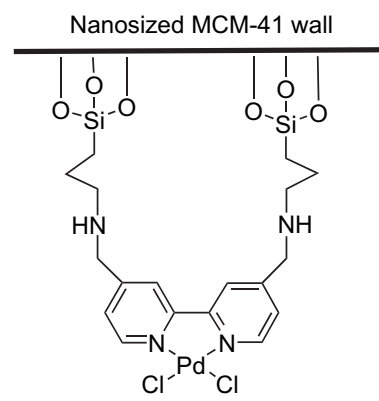

Figure 1. Nanosized MCM-41-Pd. 
Heck reaction. ${ }^{\text {9f }}$ The major advantage of this NS-MCM-41Pd with highly connective wormhole-like pores is that the reactants, salts and products are easily exchanged throughout the nanochannels to avoid the saturation of activity. ${ }^{16}$ Continuing in this direction, in this paper we present the utilization of NS-MCM-41-Pd as the catalyst for the Kumada-Corriu coupling reaction (Scheme 1).

$$
\begin{aligned}
& \mathrm{ArX}+\operatorname{Ar} \mathrm{MgBr} \frac{\mathrm{NS}-\mathrm{MCM}-41-\mathrm{Pd}(0.2-0.02 \mathrm{~mol} \%)}{\mathrm{THF}, \triangle} \mathrm{Ar}-\mathrm{Ar}^{\prime} \\
& \mathrm{X}=\mathrm{I}, \mathrm{Br}
\end{aligned}
$$

Scheme 1. Kumada-Corriu reaction.

\section{Results and discussion}

\subsection{Preparation of palladium bipyridyl anchored nanosized MCM-41}

Nanosized MCM-41 was synthesized according to the previously published procedure, ${ }^{17}$ and the size of the particles obtained was in the range of 70-120 nm, with an average pore diameter of ca. $2.7 \mathrm{~nm}$ and a surface area of $1019 \mathrm{~m}^{2} \mathrm{~g}^{-1}$. Reaction of 1 with 3-aminopropyltriethoxysilane (APTS) in the presence of $\mathrm{Et}_{3} \mathrm{~N}$ at $50{ }^{\circ} \mathrm{C}$ for $6 \mathrm{~h}$ resulted in the formation of the silylated bipyridine 2 in $96 \%$ yield. $\mathrm{PdCl}_{2}(\mathrm{PhCN})_{2}$ was one of the best starting materials for the preparation of the palladium bipyridyl complex due to the weakly coordinated benzonitrile ligand. Thus treatment of $\mathrm{PdCl}_{2}(\mathrm{PhCN})_{2}$ with $\mathbf{2}$ in dried toluene afforded the formation of palladium bipyridyl complex $\mathbf{3}$, which was subsequently subjected to the co-condensation reaction with the surface silanol groups on the pore wall of nanosized MCM-41. The unreacted silanol groups on the silica surface were then silylated by the addition of chlorotrimethylsilane at $70{ }^{\circ} \mathrm{C}$ to make the surface hydrophobic (Scheme 2). From the $\mathrm{N}_{2}$ adsorption-desorption isotherms, NS-MCM-41-Pd was found to have a BET (Brunner-Emmett-Teller) surface area of $777 \mathrm{~m}^{2} \mathrm{~g}^{-1}$ and a narrow pore size distribution of $2.5 \mathrm{~nm}$, indicating that the mesostructure of the silica remains intact. The amount of Pd complex anchored on the wall of nanosized MCM-41 was found to be $0.15 \mathrm{mmol} \mathrm{g}^{-1}$ by ICP mass analysis.

\subsection{Activity and recycling studies on NS-MCM-41-Pd}

Initially, we chose the reaction of iodobenzene (1.0 equiv) with 4-methoxyphenylmagnesium bromide ( 1.25 equiv) in the presence of NS-MCM-41-Pd $(0.2 \mathrm{~mol} \%)$ to examine the feasibility of this approach. The reaction proceeded smoothly at $50{ }^{\circ} \mathrm{C}$ and produced $99 \%$ yield of the desired product within $3 \mathrm{~h}$ (Table 1, entry 1). It has been found that the $\mathrm{MgBr}_{2}$ precipitate generated in the reaction would be deposited on the pore surface, causing a decrease in catalytic activity. ${ }^{7}$ In our system, the MgBrI salt did not slow down the reaction, presumably due to the short and highly connective channels in the mesostructures of NS-MCM41-Pd, which provide good transport of the reactants and products. After the reaction, the catalyst was recovered by centrifugation, washed with $3 \mathrm{~N} \mathrm{HCl}$ aqueous solution and THF, and dried under vacuum overnight. The recovered NS-MCM-41-Pd was then re-used in the same reaction; it was found that the catalyst retained the same level of activity for three more runs (entry 1), indicating the stability of the catalyst after the workup. Reactions of other combinations of aryl iodides and aryl Grignard reagents proceeded similarly (entries 2 and 3).

\subsection{The Kumada-Corriu reaction of aryl halides with Grignard reagents}

The results of the NS-MCM-41-Pd-catalyzed cross-coupling of aryl iodides with various Grignard reagents for a single batch reaction are shown in Table 2. All of the products were purified by column chromatography and identified by comparison with authentic samples. In the case of iodobenzene, even with ratios of substrate to catalyst up to 2000 , the

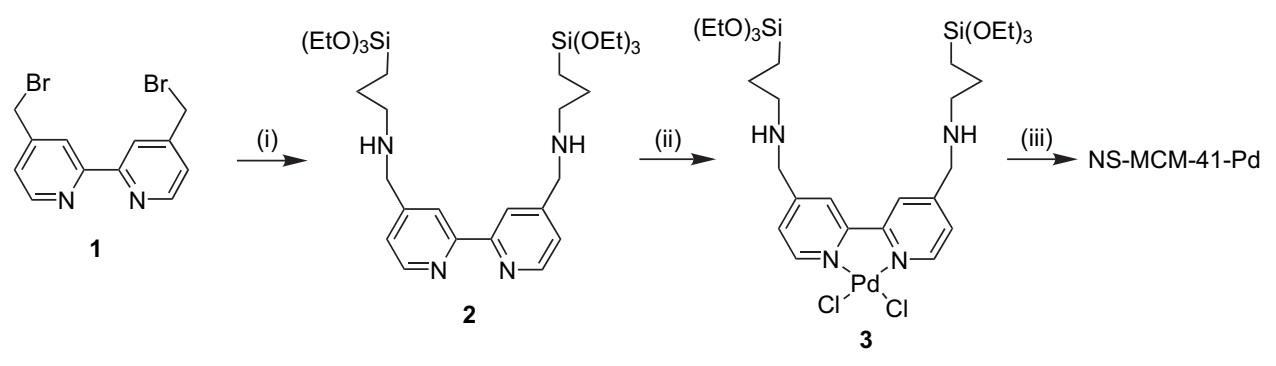

Scheme 2. Preparation of NS-MCM-41-Pd: (i) $\mathrm{H}_{2} \mathrm{~N}\left(\mathrm{CH}_{2}\right)_{3} \mathrm{Si}(\mathrm{OEt})_{3}, \mathrm{Et}_{3} \mathrm{~N}$, THF, $50{ }^{\circ} \mathrm{C}, 6 \mathrm{~h}$; (ii) $\mathrm{PdCl}_{2}\left(\mathrm{PhCN}_{2}\right.$, toluene, rt and (iii) NS-MCM-41, toluene, reflux, $48 \mathrm{~h}$, then $\mathrm{Me}_{3} \mathrm{SiCl}, 70{ }^{\circ} \mathrm{C}$.

Table 1. Recycling studies of the NS-MCM-41-Pd for the coupling of aryl iodides with arylmagnesium bromides ${ }^{\mathrm{a}}$

\begin{tabular}{llllllll}
\hline Entry & Aryl iodide & Ar' ${ }^{\prime} \mathrm{MgBr}$ & $t(\mathrm{~h})$ & & \multicolumn{2}{c}{ Yield $^{\text {b }}(\%)$} \\
\cline { 5 - 7 } & & & & First cycle & First recycle & Second recycle & Third recycle \\
\hline 1 & $\mathrm{C}_{6} \mathrm{H}_{5} \mathrm{I}$ & $4-\mathrm{CH}_{3} \mathrm{OC}_{6} \mathrm{H}_{4} \mathrm{MgBr}$ & 3 & 99 & 98 & 99 & 95 \\
2 & $\mathrm{C}_{6} \mathrm{H}_{5} \mathrm{I}$ & $2-\mathrm{C}_{4} \mathrm{H}_{3} \mathrm{SMgBr}$ & 2 & 95 & 99 & 92 & 91 \\
3 & $4-\mathrm{CH}_{3} \mathrm{OC}_{6} \mathrm{H}_{4} \mathrm{I}$ & $\mathrm{C}_{6} \mathrm{H}_{5} \mathrm{MgBr}$ & 3 & 98 & 99 & 98 & 94 \\
\hline
\end{tabular}

${ }^{\text {a }}$ Reaction conditions: in $\mathrm{THF}$ at $50^{\circ} \mathrm{C}$. $[\mathrm{ArI}] /\left[\mathrm{Ar}^{\prime} \mathrm{MgBr}\right] /[\mathrm{Pd}]=500 / 625 / 1$.

b GC yields. 
Table 2. Cross-coupling reactions of aryl iodides with Grignard reagents catalyzed by NS-MCM-41-Pd

\begin{tabular}{|c|c|c|c|c|c|c|c|}
\hline \multirow[t]{2}{*}{ Entry } & \multirow[t]{2}{*}{ Aryl iodide } & \multirow[t]{2}{*}{$\mathrm{Ar}^{\prime} \mathrm{MgBr}$} & \multirow[t]{2}{*}{$\mathrm{Pd}(\operatorname{mol} \%)$} & \multirow[t]{2}{*}{$t(\mathrm{~h})$} & \multicolumn{2}{|c|}{ Yield $^{\mathrm{b}}(\%)$} & \multirow[t]{2}{*}{ TON } \\
\hline & & & & & $\mathrm{Ar}-\mathrm{Ar}^{\prime}$ & $\overline{\mathrm{Ar}^{\prime}-\mathrm{Ar}^{\prime}}$ & \\
\hline 1 & $\mathrm{C}_{6} \mathrm{H}_{5} \mathrm{I}$ & $\mathrm{C}_{6} \mathrm{H}_{5} \mathrm{MgBr}$ & 0.05 & 8 & $98(90)$ & 0 & 1960 \\
\hline 2 & $\mathrm{C}_{6} \mathrm{H}_{5} \mathrm{I}$ & $2-\mathrm{C}_{4} \mathrm{H}_{3} \mathrm{SMgBr}$ & 0.05 & 20 & $97(91)$ & 0 & 1940 \\
\hline 3 & $\mathrm{C}_{6} \mathrm{H}_{5} \mathrm{I}$ & 4- $\mathrm{CH}_{3} \mathrm{OC}_{6} \mathrm{H}_{4} \mathrm{MgBr}$ & 0.05 & 24 & (95) & 0 & 1900 \\
\hline 4 & $\mathrm{C}_{6} \mathrm{H}_{5} \mathrm{I}$ & $\mathrm{CH}_{2}=\mathrm{CHMgBr}$ & 0.2 & 3 & 67 & $\mathrm{ND}^{\mathrm{c}}$ & 335 \\
\hline 5 & 4- $\mathrm{CH}_{3} \mathrm{C}_{6} \mathrm{H}_{4} \mathrm{I}$ & $\mathrm{C}_{6} \mathrm{H}_{5} \mathrm{MgBr}$ & 0.05 & 16 & $97(89)$ & 10 & 1940 \\
\hline 6 & $4-\mathrm{CH}_{3} \mathrm{C}_{6} \mathrm{H}_{4} \mathrm{I}$ & $2-\mathrm{C}_{4} \mathrm{H}_{3} \mathrm{SMgBr}$ & 0.2 & 3 & (82) & 0 & 410 \\
\hline 7 & 4- $\mathrm{CH}_{3} \mathrm{C}_{6} \mathrm{H}_{4} \mathrm{I}$ & 4- $\mathrm{CH}_{3} \mathrm{OC}_{6} \mathrm{H}_{4} \mathrm{MgBr}$ & 0.2 & 3 & (76) & 0 & 380 \\
\hline
\end{tabular}

a Reaction conditions: in $\mathrm{THF}$ at $50^{\circ} \mathrm{C}$. $[\mathrm{ArI}] /\left[\mathrm{Ar}^{\prime} \mathrm{MgBr}\right]=1 / 1.25$.

${ }^{\mathrm{b}} \mathrm{GC}$ yields. Isolated yields are given in parenthesis.

c Not detected.

turnover numbers can reach 1960 (Table 2, entries 1-3). Remarkably, it was found that vinylmagnesium bromide can also be employed in this coupling reaction to produce styrene in good yield (entry 4). As illustrated in entries 57 , other aryl iodides such as 4-iodotoluene also underwent the reaction smoothly, leading to the formation of the desired products in high yields. Except for entry 5, homocoupling products were not observed.

With regard to aryl bromides, higher reaction temperatures together with the addition of $\mathrm{PPh}_{3}$ are required (Table 3). As the oxidative addition for aryl bromides is slower than that of the iodides, the addition of $\mathrm{PPh}_{3}$ presumably stabilizes the palladium species before oxidative addition occurs. As shown in entries 1-3 of Table 3, bromobenzene reacted with aryl- and 2-thienylmagnesium bromides to produce the corresponding products in high yields. The use of toluene as a solvent for the coupling of bromobenzene and 4methoxyphenylmagnesium bromide showed similar activity as in THF (entries 3 and 4). For electron-rich substrates such as 4-bromoanisole, the reaction provided not only the crosscoupling product but also a small amount of homocoupling by-products (entries 5-7). The coupling reaction of sterically hindered 2-methoxybromobenzene and 2-bromomesitylene with Grignard reagents did occur although a longer reaction time was required (entries 8-10).

As expected, the oxidative addition of a $\mathrm{C}-\mathrm{Cl}$ bond to palladium did not occur in this system, so the reaction of 4-bromochlorobenzene with aryl- and heteroarylmagnesium bromides resulted in the formation of chloro-substituted biaryl compounds. It should be noted that the amount of Pd loading for a single run can be as low as $0.02 \mathrm{~mol} \%$. Under such condition, cross-coupling products were obtained in high yields along with only a small amount of homocoupling by-products (entries 11-13). Attempts to activate the aryl chloride bond by the addition of $\mathrm{PPh}_{2} \mathrm{Me}$, $\mathrm{PPhMe}_{2}$ and $\mathrm{PMe}_{3}$ instead of $\mathrm{PPh}_{3}$ were unsuccessful. The Kumada-Corriu reaction could be achieved using heteroaryl bromides. For example, 2-bromothiophene reacted with arylmagnesium bromides effectively, producing biaryls in high yields (entries 14-16). 3-Bromothiophene gave a slower reaction; the products were obtained in moderate yields (entries 17-19). In the case of using 4-methoxyphenylmagnesium bromide, the homocoupling by-product, 4,4'-dimethoxybiphenyl, was formed in significant amount

Table 3. Cross-coupling reactions of aryl bromides with Grignard reagents catalyzed by NS-MCM-41-Pd

\begin{tabular}{|c|c|c|c|c|c|c|c|}
\hline \multirow[t]{2}{*}{ Entry } & \multirow[t]{2}{*}{ Aryl bromide } & \multirow[t]{2}{*}{$\mathrm{Ar}^{\prime} \mathrm{MgBr}$} & \multirow[t]{2}{*}{$\mathrm{Pd}(\mathrm{mol} \%)$} & \multirow[t]{2}{*}{$t(\mathrm{~h})$} & \multicolumn{2}{|c|}{ Yield $^{\mathrm{b}}(\%)$} & \multirow[t]{2}{*}{ TON } \\
\hline & & & & & $\mathrm{Ar}-\mathrm{Ar}^{\prime}$ & $\mathrm{Ar}^{\prime}-\mathrm{Ar}^{\prime}$ & \\
\hline 1 & $\mathrm{C}_{6} \mathrm{H}_{5} \mathrm{Br}$ & $\mathrm{C}_{6} \mathrm{H}_{5} \mathrm{MgBr}$ & 0.05 & 16 & 94 & 0 & 1880 \\
\hline 2 & $\mathrm{C}_{6} \mathrm{H}_{5} \mathrm{Br}$ & $2-\mathrm{C}_{4} \mathrm{H}_{3} \mathrm{SMgBr}$ & 0.2 & 8 & $88(63)$ & 0 & 440 \\
\hline 3 & $\mathrm{C}_{6} \mathrm{H}_{5} \mathrm{Br}$ & $4-\mathrm{CH}_{3} \mathrm{OC}_{6} \mathrm{H}_{4} \mathrm{MgBr}$ & 0.05 & 24 & $(90)$ & 0 & 1800 \\
\hline $4^{c}$ & $\mathrm{C}_{6} \mathrm{H}_{5} \mathrm{Br}$ & $4-\mathrm{CH}_{3} \mathrm{OC}_{6} \mathrm{H}_{4} \mathrm{MgBr}$ & 0.05 & 24 & $(90)$ & 0 & 1800 \\
\hline 5 & 4- $\mathrm{CH}_{3} \mathrm{OC}_{6} \mathrm{H}_{4} \mathrm{Br}$ & $\mathrm{C}_{6} \mathrm{H}_{5} \mathrm{MgBr}$ & 0.05 & 24 & 98 & 12 & 1960 \\
\hline 6 & $4-\mathrm{CH}_{3} \mathrm{OC}_{6} \mathrm{H}_{4} \mathrm{Br}$ & $2-\mathrm{C}_{4} \mathrm{H}_{3} \mathrm{SMgBr}$ & 0.2 & 12 & 80 & 3 & 400 \\
\hline 7 & $4-\mathrm{CH}_{3} \mathrm{OC}_{6} \mathrm{H}_{4} \mathrm{Br}$ & $4-\mathrm{CH}_{3} \mathrm{OC}_{6} \mathrm{H}_{4} \mathrm{MgBr}$ & 0.05 & 24 & $(92)$ & 2 & 1840 \\
\hline 8 & $2-\mathrm{CH}_{3} \mathrm{OC}_{6} \mathrm{H}_{4} \mathrm{Br}$ & $\mathrm{C}_{6} \mathrm{H}_{5} \mathrm{MgBr}$ & 0.2 & 24 & 99 & 8 & 495 \\
\hline 9 & $2-\mathrm{CH}_{3} \mathrm{OC}_{6} \mathrm{H}_{4} \mathrm{Br}$ & $2-\mathrm{C}_{4} \mathrm{H}_{3} \mathrm{SMgBr}$ & 0.2 & 24 & 95 & 6 & 475 \\
\hline 10 & 2-Bromomesitylene & 4- $\mathrm{CH}_{3} \mathrm{OC}_{6} \mathrm{H}_{4} \mathrm{MgBr}$ & 0.2 & 36 & 93 & 0 & 465 \\
\hline 11 & 4- $\mathrm{BrC}_{6} \mathrm{H}_{4} \mathrm{Cl}$ & $\mathrm{C}_{6} \mathrm{H}_{5} \mathrm{MgBr}$ & 0.02 & 24 & $98(82)$ & 17 & 4900 \\
\hline 12 & $4-\mathrm{BrC}_{6} \mathrm{H}_{4} \mathrm{Cl}$ & $2-\mathrm{C}_{4} \mathrm{H}_{3} \mathrm{SMgBr}$ & 0.02 & 36 & $98(97)$ & 5 & 4900 \\
\hline 13 & $4-\mathrm{BrC}_{6} \mathrm{H}_{4} \mathrm{Cl}$ & 4- $\mathrm{CH}_{3} \mathrm{OC}_{6} \mathrm{H}_{4} \mathrm{MgBr}$ & 0.02 & 48 & $(85)$ & 10 & 4250 \\
\hline 14 & 2-Bromothiophene & $\mathrm{C}_{6} \mathrm{H}_{5} \mathrm{MgBr}$ & 0.2 & 15 & 99 & 0 & 495 \\
\hline 15 & 2-Bromothiophene & $2-\mathrm{C}_{4} \mathrm{H}_{3} \mathrm{SMgBr}$ & 0.2 & 24 & $95(75)$ & 0 & 475 \\
\hline 16 & 2-Bromothiophene & 4- $\mathrm{CH}_{3} \mathrm{OC}_{6} \mathrm{H}_{4} \mathrm{MgBr}$ & 0.05 & 18 & 87 & 3 & 1740 \\
\hline 17 & 3-Bromothiophene & $\mathrm{C}_{6} \mathrm{H}_{5} \mathrm{MgBr}$ & 0.2 & 40 & $(61)$ & 0 & 305 \\
\hline 18 & 3-Bromothiophene & $2-\mathrm{C}_{4} \mathrm{H}_{3} \mathrm{SMgBr}$ & 0.2 & 48 & $47(40)$ & 5 & 235 \\
\hline 19 & 3-Bromothiophene & $4-\mathrm{CH}_{3} \mathrm{OC}_{6} \mathrm{H}_{4} \mathrm{MgBr}$ & 0.2 & 24 & (59) & 20 & 295 \\
\hline $20^{\mathrm{d}}$ & Benzyl bromide & $\mathrm{C}_{6} \mathrm{H}_{5} \mathrm{MgBr}$ & 0.2 & 3 & $82(70)$ & 4 & 410 \\
\hline
\end{tabular}

${ }^{\text {a }}$ Reaction conditions: in refluxed THF. $[\mathrm{ArBr}] /\left[\mathrm{Ar}^{\prime} \mathrm{MgBr}\right]=1 / 1.25,\left[\mathrm{PPh}_{3}\right] /[\mathrm{Pd}]=2 / 1$.

${ }^{\mathrm{b}} \mathrm{GC}$ yields. Isolated yields are given in parenthesis.

${ }^{\text {c }}$ In toluene at $90^{\circ} \mathrm{C}$.

d At room temperature in the absence of $\mathrm{PPh}_{3}$. 
(entry 19). This system could also be successfully applied to the coupling of benzyl bromide with phenylmagnesium bromide. In this way, diphenylmethane was obtained in $82 \%$ yield at room temperature without the addition of $\mathrm{PPh}_{3}$ (entry 20).

\subsection{Leaching test for NS-MCM-41-Pd}

It would be a concern if the leaching of active species into the solution is substantial. A hot-filtration experiment was performed to check the leaching of $\mathrm{Pd}$ species. After 30 min of reaction at $50{ }^{\circ} \mathrm{C}$, the coupling of iodobenzene with 4-methoxyphenylmagnesium bromide in the presence of 0.2 mol \% NS-MCM-41-Pd gave 4-methoxybiphenyl in $35 \%$ GC yield. The reaction mixture was filtered through a dried Celite pad under nitrogen to remove any undissolved fine particles and magnesium salt. The clear filtrate was then stirred at $50{ }^{\circ} \mathrm{C}$ and followed by GC. We found that after the removal of NS-MCM-41-Pd, the yield of the cross-coupling product stayed around $40 \%$ during the period $0.5-3 \mathrm{~h}$ (Fig. 2). The yield increases only slightly after filtration. In contrast, if the catalyst was not filtered off, the yield would reach $99 \%$ at $3 \mathrm{~h}$ (Table 1 , entry 1 ). In addition, the clear filtrate analyzed by atomic absorption showed less than $3 \mathrm{ppm}$ of palladium in the reaction media. The amount of Pd leaching is slight, comparable to that of mesoporous silicasupported palladium catalysts for other types of carboncarbon bond cross-coupling reactions. ${ }^{15,16,18}$

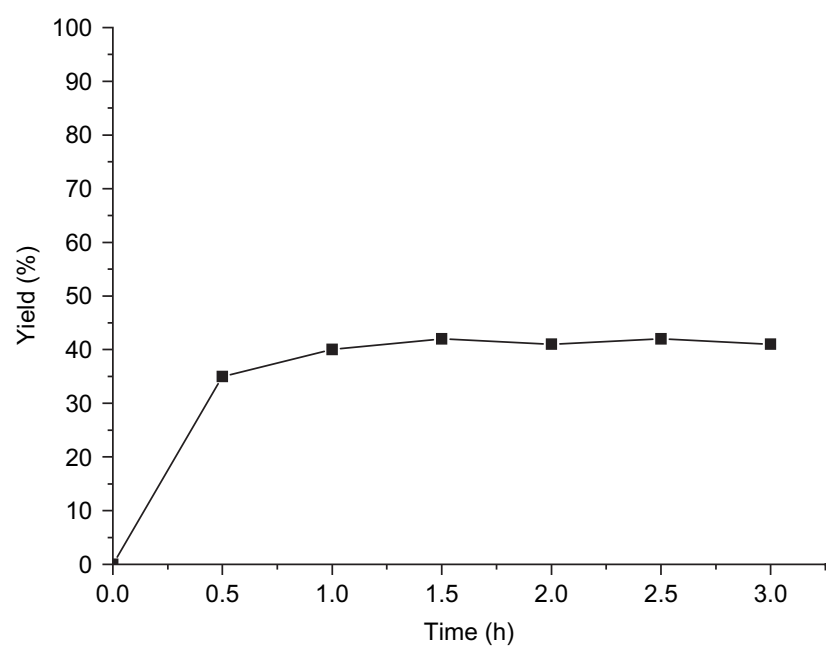

Figure 2. Plot of yields versus time for the hot-filtration experiment. The NS-MCM-41-Pd was filtered off after $0.5 \mathrm{~h}$ reaction at $50^{\circ} \mathrm{C}$. $\left[\mathrm{C}_{6} \mathrm{H}_{5} \mathrm{I}\right] /[4-$ $\left.\mathrm{CH}_{3} \mathrm{OC}_{6} \mathrm{H}_{4} \mathrm{MgBr}\right] /[\mathrm{Pd}]=500 / 625 / 1$.

\section{Conclusion}

We have shown that NS-MCM-41-Pd can catalyze the coupling of various aryl halides with arylmagnesium bromides to yield the corresponding biaryls in good to high yields. The loading of $\mathrm{Pd}$ in a single batch reaction can be reduced to as low as $0.02 \mathrm{~mol} \%$. The nanosized MCM-41 provides easy transport of the reactants and products such that no loss of activity was observed after prolonged use. The catalyst can be easily recovered and re-used several times without loss of activity. Further work is in progress to develop new carbon-carbon bond formations catalyzed by this catalytic system.

\section{Experimental}

\subsection{General}

All reactions involving air- and moisture-sensitive conditions were carried out in a dry nitrogen atmosphere. THF and toluene were distilled from sodium benzophenone ketyl. The chemicals were purchased from commercial suppliers and were used without further purification. 4,4'-Bis(bromomethyl)-2,2'-bipyridine $1,{ }^{19} \mathrm{PdCl}_{2}(\mathrm{PhCN})_{2}{ }^{20}$ and nanosized MCM- $41^{17}$ were prepared according to previously published procedures. Melting points were recorded using melting point apparatus and were uncorrected. All ${ }^{1} \mathrm{H}$ and ${ }^{13} \mathrm{C}$ NMR spectra were recorded in $\mathrm{CDCl}_{3}$ or $\mathrm{C}_{6} \mathrm{D}_{6}$ solution at $25^{\circ} \mathrm{C}$ on Varian $400 \mathrm{NMR}$ spectrometer. GC analysis was performed on SRI 8610C equipped with a fused silica capillary column.

\subsection{Preparation of the functionalized bipyridine ligand (2)}

$\mathrm{Et}_{3} \mathrm{~N}(1.1 \mathrm{~mL}, 10 \mathrm{mmol})$ and 3-aminopropyltriethoxysilane $(1.18 \mathrm{~mL}, 10 \mathrm{mmol})$ were added to a solution of $4,4^{\prime}$-bis(bromomethyl)-2,2'-bipyridine $1(0.171 \mathrm{~g}, 0.5 \mathrm{mmol})$ in $\mathrm{THF}$, and the mixture was stirred at $50{ }^{\circ} \mathrm{C}$ for $6 \mathrm{~h}$. After cooling the solution to room temperature, hexane $(20 \mathrm{~mL})$ was added and the mixture was filtered through a short $\mathrm{MgSO}_{4}$ column to remove the ammonium salt. The clear solution was then concentrated and dried under vacuum at $50{ }^{\circ} \mathrm{C}$ for $24 \mathrm{~h}$ to produce the title compound as a pale yellow viscous oil in $96 \%$ yield. ${ }^{1} \mathrm{H}$ NMR $\left(\mathrm{C}_{6} \mathrm{D}_{6}, 400 \mathrm{MHz}\right) \delta 0.67-$ $0.73(\mathrm{~m}, 4 \mathrm{H}), 1.14(\mathrm{t}, J=7.0 \mathrm{~Hz}, 18 \mathrm{H}), 1.63-1.68(\mathrm{~m}, 4 \mathrm{H})$, $2.42(\mathrm{t}, J=7.0 \mathrm{~Hz}, 4 \mathrm{H}), 3.50(\mathrm{~s}, 4 \mathrm{H}), 3.75(\mathrm{q}, J=7.0 \mathrm{~Hz}$, $12 \mathrm{H}), 7.07$ (d, J=4.2 Hz, 2H), 8.57 (d, J=4.2 Hz, 2H), $8.78(\mathrm{~s}, 2 \mathrm{H}) ;{ }^{13} \mathrm{C} \mathrm{NMR}\left(\mathrm{C}_{6} \mathrm{D}_{6}, 100 \mathrm{MHz}\right) \delta 8.4(2 \mathrm{C}), 18.6$ (6C), 23.8 (2C), 52.4 (2C), 53.0 (2C), 58.4 (6C), 120.7 (2C), 123.1 (2C), 149.3 (2C), 151.2 (2C), 156.8 (2C). HRMS: $m / z$ Calcd for $\mathrm{C}_{30} \mathrm{H}_{54} \mathrm{~N}_{4} \mathrm{O}_{6} \mathrm{Si}_{2}, 622.3582$; found, 622.3539 .

\subsection{Preparation of palladium grafted nanosized MCM-41}

A solution of palladium complex 3 prepared in situ by mixing ligand 2 (299 $\mathrm{mg}, 0.48 \mathrm{mmol})$ and $\mathrm{PdCl}_{2}(\mathrm{PhCN})_{2}$ (184 $\mathrm{mg}, 0.48 \mathrm{mmol})$ in toluene $(20 \mathrm{~mL})$ under nitrogen for $0.5 \mathrm{~h}$ was transferred into a toluene $(20 \mathrm{~mL})$ suspension of fresh calcined nanosized MCM-41 (3.0 g). The mixture was stirred under reflux for $48 \mathrm{~h}$. After cooling to $70^{\circ} \mathrm{C}$, chlorotrimethylsilane $(1.5 \mathrm{~mL})$ was added to consume the unreacted silanol groups. Upon cooling, the light yellowbrown suspension was collected by centrifugation, subsequently washed with toluene, $\mathrm{MeOH}, \mathrm{H}_{2} \mathrm{O}$ and acetone $(2 \times 40 \mathrm{~mL}$ for each washing), and dried under vacuum overnight to afford a pale yellow solid. The amount of Pd complex anchored on the wall of nanosized MCM-41 was quantified to be $0.15 \mathrm{mmol} \mathrm{g}^{-1}$ by ICP mass analysis.

\subsection{General procedure for the Kumada-Corriu reaction using NS-MCM-41-Pd}

Under a nitrogen atmosphere, a Schlenk tube was charged with NS-MCM-41-Pd (40 mg, $\left.6.0 \times 10^{-3} \mathrm{mmol}\right)$, aryl halide 
(12.0 mmol; for aryl bromide, $1.2 \times 10^{-2} \mathrm{mmol}$ of $\mathrm{PPh}_{3}$ was added), THF (20 $\mathrm{mL})$ and Grignard reagent $(15.0 \mathrm{mmol})$. The mixture was stirred at $50{ }^{\circ} \mathrm{C}$ or under refluxing conditions. After cooling to room temperature, $3 \mathrm{~N} \mathrm{HCl}$ was added and extracted with EtOAc. The organic layer was dried over $\mathrm{MgSO}_{4}$ and the solvent was removed under vacuum. Column chromatography on silica gel afforded the desired product.

4.4.1. 4-Methoxybiphenyl. White solid. $\mathrm{Mp} 85-87^{\circ} \mathrm{C}$ from EtOH (lit. $\left.{ }^{21} 89^{\circ} \mathrm{C}\right) .{ }^{1} \mathrm{H}$ NMR $\left(\mathrm{CDCl}_{3}, 400 \mathrm{MHz}\right) \delta 3.85$ (s, $3 \mathrm{H}), 6.95(\mathrm{~d}, J=6.8 \mathrm{~Hz}, 2 \mathrm{H}), 7.30-7.32(\mathrm{~m}, 1 \mathrm{H}), 7.40-$ $7.43(\mathrm{~m}, 2 \mathrm{H}), 7.51-7.55(\mathrm{~m}, 4 \mathrm{H}) ;{ }^{13} \mathrm{C} \mathrm{NMR}\left(\mathrm{CDCl}_{3}\right.$, $100 \mathrm{MHz}) \delta 55.5,113.9$ (2C), 126.3, 126.4 (2C), 127.7 (2C), 128.3 (2C), 133.3, 140.3, 158.5.

4.4.2. 2-Phenylthiophene. White solid. $\mathrm{Mp} 35-36{ }^{\circ} \mathrm{C}$ from EtOH (lit. $\left.{ }^{21} 35^{\circ} \mathrm{C}\right) .{ }^{1} \mathrm{H} \mathrm{NMR}\left(\mathrm{CDCl}_{3}, 400 \mathrm{MHz}\right) \delta 7.07-$ $7.09(\mathrm{~m}, 1 \mathrm{H}), 7.26-7.32(\mathrm{~m}, 3 \mathrm{H}), 7.36-7.40 \quad(\mathrm{~m}$, 2H), 7.61-7.63 (m, 2H); ${ }^{13} \mathrm{C} \mathrm{NMR}\left(\mathrm{CDCl}_{3}, 100 \mathrm{MHz}\right)$ $\delta 122.7,124.4,125.6(2 \mathrm{C}), 127.0,127.6,128.5(2 \mathrm{C})$, 133.9, 143.9 .

4.4.3. Biphenyl. White solid. $\mathrm{Mp} 71-72{ }^{\circ} \mathrm{C}$ from $\mathrm{EtOH}$ (lit. $\left.{ }^{22} 70-71^{\circ} \mathrm{C}\right) .{ }^{1} \mathrm{H}$ NMR $\left(\mathrm{CDCl}_{3}, 400 \mathrm{MHz}\right) \delta 7.20-7.75$ $(\mathrm{m}, 10 \mathrm{H}) ;{ }^{13} \mathrm{C} \mathrm{NMR}\left(\mathrm{CDCl}_{3}, 100 \mathrm{MHz}\right) \delta 126.8(2 \mathrm{C})$, 126.9 (4C), 128.3 (4C), 140.8 (2C).

4.4.4. Styrene. Colourless liquid. ${ }^{23}{ }^{1} \mathrm{H}$ NMR $\left(\mathrm{CDCl}_{3}\right.$, $400 \mathrm{MHz}) \delta 5.30(\mathrm{~d}, J=10.8 \mathrm{~Hz}, 1 \mathrm{H}), 5.81(\mathrm{~d}, J=17.6 \mathrm{~Hz}$, $1 \mathrm{H}), 6.78(\mathrm{dd}, J=10.8,17.6 \mathrm{~Hz}, 1 \mathrm{H}), 7.29-7.30(\mathrm{~m}, 1 \mathrm{H})$, $7.32-7.40(\mathrm{~m}, 2 \mathrm{H}), 7.46-7.48(\mathrm{~m}, 2 \mathrm{H}) ;{ }^{13} \mathrm{C} \mathrm{NMR}\left(\mathrm{CDCl}_{3}\right.$, $100 \mathrm{MHz}) \delta 113.5,125.8$ (2C), 127.4, 128.1 (2C), 136.4, 137.0.

4.4.5. 4-Methylbiphenyl. White solid. Mp $43-45^{\circ} \mathrm{C}$ from EtOH (lit. $\left.{ }^{24} 44.5-46.5^{\circ} \mathrm{C}\right) .{ }^{1} \mathrm{H}$ NMR $\left(\mathrm{CDCl}_{3}, 400 \mathrm{MHz}\right)$ $\delta 2.42(\mathrm{~s}, 3 \mathrm{H}), 7.24-7.28(\mathrm{~m}, 2 \mathrm{H}), 7.32-7.36(\mathrm{~m}, 1 \mathrm{H})$, 7.42-7.51 (m, 2H), 7.51-7.53 (m, 2H), 7.58-7.61 (m, $2 \mathrm{H}) ;{ }^{13} \mathrm{C} \mathrm{NMR}\left(\mathrm{CDCl}_{3}, 100 \mathrm{MHz}\right) \delta 21.5,126.6,128.3$ (2C), 128.4 (2C), 129.0 (2C), 129.1 (2C), 136.5, 137.9, 140.6 .

4.4.6. 2-p-Tolylthiophene. White solid. $\mathrm{Mp} 67-69^{\circ} \mathrm{C}$ from EtOH (lit. $\left.{ }^{25} 63-64{ }^{\circ} \mathrm{C}\right) .{ }^{1} \mathrm{H}$ NMR $\left(\mathrm{CDCl}_{3}, 400 \mathrm{MHz}\right) \delta 2.37$ $(\mathrm{s}, 3 \mathrm{H}), 7.05-7.07(\mathrm{~m}, 1 \mathrm{H}), 7.18(\mathrm{~d}, J=7.8 \mathrm{~Hz}, 2 \mathrm{H}), 7.23-$ $7.27(\mathrm{~m}, 2 \mathrm{H}), 7.50(\mathrm{~d}, J=7.8 \mathrm{~Hz}, 2 \mathrm{H}) ;{ }^{13} \mathrm{C} \mathrm{NMR}\left(\mathrm{CDCl}_{3}\right.$, $100 \mathrm{MHz}) \delta 21.6,122.2,123.9,125.5$ (2C), 127.5, 129.1 (2C), 131.2, 136.9, 144.1.

4.4.7. 4'-Methoxy-4-methylbiphenyl. White solid. Mp $113-114^{\circ} \mathrm{C}$ from EtOH (lit. $\left.{ }^{26} 109-110^{\circ} \mathrm{C}\right) .{ }^{1} \mathrm{H}$ NMR $\left(\mathrm{CDCl}_{3}, 400 \mathrm{MHz}\right) \delta 2.38(\mathrm{~s}, 3 \mathrm{H}), 3.84(\mathrm{~s}, 3 \mathrm{H}), 6.95(\mathrm{~d}$, $J=8.8 \mathrm{~Hz}, 2 \mathrm{H}), 7.21(\mathrm{~d}, J=8.0 \mathrm{~Hz}, 2 \mathrm{H}), 7.44(\mathrm{~d}, J=8.0 \mathrm{~Hz}$, $2 \mathrm{H}), 7.50(\mathrm{~d}, J=8.8 \mathrm{~Hz}, 2 \mathrm{H}) ;{ }^{13} \mathrm{C} \mathrm{NMR}\left(\mathrm{CDCl}_{3}, 100 \mathrm{MHz}\right)$ $\delta$ 21.5, 55.5, 113.8 (2C), 126.2 (2C), 127.6 (2C), 129.0 (2C), 133.3, 135.9, 137.5, 158.3.

4.4.8. 4,4' -Dimethoxybiphenyl. Pale yellow solid. Mp 178$180{ }^{\circ} \mathrm{C}$ from $\mathrm{EtOH}$ (lit. $\left.{ }^{26} 178-179{ }^{\circ} \mathrm{C}\right) .{ }^{1} \mathrm{H} \mathrm{NMR}\left(\mathrm{CDCl}_{3}\right.$, $400 \mathrm{MHz}) \delta 3.84(\mathrm{~s}, 6 \mathrm{H}), 6.96(\mathrm{~d}, J=8.8 \mathrm{~Hz}, 4 \mathrm{H}), 7.48(\mathrm{~d}$, $J=8.8 \mathrm{~Hz}, 4 \mathrm{H}) ;{ }^{13} \mathrm{C} \mathrm{NMR}\left(\mathrm{CDCl}_{3}, 100 \mathrm{MHz}\right) \delta 55.5(2 \mathrm{C})$, 114.4 (4C), 127.3 (4C), 133.0 (2C), 158.0 (2C).
4.4.9. 2-Methoxybiphenyl. Colourless oil. ${ }^{21}{ }^{1} \mathrm{H}$ NMR $\left(\mathrm{CDCl}_{3}, 400 \mathrm{MHz}\right) \delta 3.84(\mathrm{~s}, 3 \mathrm{H}), 7.00-7.10(\mathrm{~m}, 2 \mathrm{H})$, 7.34-7.38 (m, 3H), 7.43-7.47 (m, 2H), 7.57-7.59 (m, 2H); ${ }^{13} \mathrm{C} \mathrm{NMR}\left(\mathrm{CDCl}_{3}, 100 \mathrm{MHz}\right) \delta 55.6,110.9,120.4,126.5$, 127.6 (2C), 128.2, 129.1 (2C), 130.2, 130.4, 138.0, 155.8.

4.4.10. 2-(2-Methoxyphenyl)thiophene. Pale yellow oil. ${ }^{27}$ ${ }^{1} \mathrm{H} \mathrm{NMR}\left(\mathrm{CDCl}_{3}, 400 \mathrm{MHz}\right) \delta 3.94(\mathrm{~s}, 3 \mathrm{H}), 6.99-7.04$ (m, 2H), 7.10-7.13 (m, 1H), 7.24-7.30 (m, 1H), 7.33-7.35 $(\mathrm{m}, 1 \mathrm{H}), 7.52-7.54(\mathrm{~m}, 1 \mathrm{H}), 7.68(\mathrm{~d}, J=8.0 \mathrm{~Hz}, 1 \mathrm{H}) ;{ }^{13} \mathrm{C}$ NMR $\left(\mathrm{CDCl}_{3}, 100 \mathrm{MHz}\right) \delta 55.6,111.2,120.5,122.9$, $124.9,125.0,126.4,127.9,128.1,138.9,154.9$.

4.4.11. 4'-Methoxy-2,4,6-trimethylbiphenyl. Mp 73$75^{\circ} \mathrm{C}$ from EtOH (lit. $\left.{ }^{28} 74-75^{\circ} \mathrm{C}\right) .{ }^{1} \mathrm{H}$ NMR $\left(\mathrm{CDCl}_{3}\right.$, $400 \mathrm{MHz}) \delta 2.04(\mathrm{~s}, 6 \mathrm{H}), 2.35(\mathrm{~s}, 3 \mathrm{H}), 3.87(\mathrm{~s}, 3 \mathrm{H}), 6.95-$ $6.99(\mathrm{~m}, 4 \mathrm{H}), 7.05-7.08(\mathrm{~m}, 2 \mathrm{H}) ;{ }^{13} \mathrm{C} \mathrm{NMR}\left(\mathrm{CDCl}_{3}\right.$, $100 \mathrm{MHz}) \delta 21.2(2 \mathrm{C}), 21.4,55.3,113.4(2 \mathrm{C}), 127.6(2 \mathrm{C})$, 129.98 (2C), 132.8, 136.0, 138.2, 157.5.

4.4.12. 4-Chlorobiphenyl. White solid. $\mathrm{Mp} 74-76{ }^{\circ} \mathrm{C}$ from EtOH (lit. $\left.{ }^{24} 75-77{ }^{\circ} \mathrm{C}\right) .{ }^{1} \mathrm{H} \mathrm{NMR}\left(\mathrm{CDCl}_{3}, 400 \mathrm{MHz}\right) \delta 7.34$ $7.45(\mathrm{~m}, 5 \mathrm{H}), 7.50-7.56(\mathrm{~m}, 4 \mathrm{H}) ;{ }^{13} \mathrm{C} \mathrm{NMR}\left(\mathrm{CDCl}_{3}\right.$, $100 \mathrm{MHz}) \delta 126.6$ (2C), 127.2, 128.3 (2C), 128.5 (2C), 128.6 (2C), 132.9, 139.2, 139.5 .

4.4.13. 2-(4-Chlorophenyl)thiophene. White solid. Mp 83$84{ }^{\circ} \mathrm{C}$ from EtOH (lit. $\left.{ }^{29} 81-82.5^{\circ} \mathrm{C}\right) .{ }^{1} \mathrm{H} \mathrm{NMR}\left(\mathrm{CDCl}_{3}\right.$, $400 \mathrm{MHz}) \delta$ 7.05-7.08 (m, 1H), 7.27-7.28 (m, 2H), 7.33 $(\mathrm{d}, J=8.0 \mathrm{~Hz}, 2 \mathrm{H}), 7.52(\mathrm{~d}, J=8.0 \mathrm{~Hz}, 2 \mathrm{H}) ;{ }^{13} \mathrm{C} \mathrm{NMR}$ $\left(\mathrm{CDCl}_{3}, 100 \mathrm{MHz}\right) \delta 123.1,124.8,126.7,127.7$ (2C), 128.6 (2C), 132.5, 132.7, 142.6.

4.4.14. $4^{\prime}$-Chloro-4-methoxybiphenyl. White solid. Mp 114-115 ${ }^{\circ} \mathrm{C}$ from EtOH (lit. ${ }^{30} 113-114{ }^{\circ} \mathrm{C}$ ). ${ }^{1} \mathrm{H}$ NMR $\left(\mathrm{CDCl}_{3}, 400 \mathrm{MHz}\right) \delta 3.84(\mathrm{~s}, 3 \mathrm{H}), 6.96(\mathrm{~d}, J=8.4 \mathrm{~Hz}, 2 \mathrm{H})$, $7.36(\mathrm{~d}, J=8.8 \mathrm{~Hz}, 2 \mathrm{H}), 7.44-7.48(\mathrm{~m}, 4 \mathrm{H}) ;{ }^{13} \mathrm{C} \mathrm{NMR}$ $\left(\mathrm{CDCl}_{3}, 100 \mathrm{MHz}\right) \delta 55.5,114.0$ (2C), 127.5 (2C), 127.6 (2C), 128.4, 132.2 (2C), 132.6, 138.8, 158.7.

4.4.15. 2,2'-Bithienyl. White solid. $\mathrm{Mp} 32-34{ }^{\circ} \mathrm{C}$ from EtOH (lit. $\left.{ }^{31} 33{ }^{\circ} \mathrm{C}\right) .{ }^{1} \mathrm{H}$ NMR $\left(\mathrm{CDCl}_{3}, 400 \mathrm{MHz}\right) \delta 7.01-$ $7.04(\mathrm{~m}, 2 \mathrm{H}), 7.19-7.22(\mathrm{~m}, 4 \mathrm{H}) ;{ }^{13} \mathrm{C} \mathrm{NMR}\left(\mathrm{CDCl}_{3}\right.$, $100 \mathrm{MHz}) \delta 123.4$ (2C), 124.0 (2C), 127.3 (2C), 136.9 (2C).

4.4.16. 3-Phenylthiophene. White solid. $\mathrm{Mp} 89-91{ }^{\circ} \mathrm{C}$ from EtOH (lit. $\left.{ }^{32} 89{ }^{\circ} \mathrm{C}\right) .{ }^{1} \mathrm{H}$ NMR $\left(\mathrm{CDCl}_{3}, 400 \mathrm{MHz}\right) \delta 7.29$ $7.33(\mathrm{~m}, 1 \mathrm{H}), 7.38-7.44(\mathrm{~m}, 4 \mathrm{H}), 7.46-7.47(\mathrm{~m}, 1 \mathrm{H})$, 7.60-7.63 (m, 2H); ${ }^{13} \mathrm{C} \mathrm{NMR}\left(\mathrm{CDCl}_{3}, 100 \mathrm{MHz}\right) \delta 119.9$, 125.8, 125.9, 126.0 (2C), 126.7, 128.4 (2C), 135.4, 141.8.

4.4.17. 2,3'-Bithienyl. Brown crystal. Mp $62-64{ }^{\circ} \mathrm{C}$ from EtOH (lit. $\left.{ }^{31} 65^{\circ} \mathrm{C}\right) .{ }^{1} \mathrm{H}$ NMR $\left(\mathrm{CDCl}_{3}, 400 \mathrm{MHz}\right) \delta 7.03$ $7.05(\mathrm{~m}, 1 \mathrm{H}), 7.20-7.22(\mathrm{~m}, 2 \mathrm{H}), 7.31-7.35(\mathrm{~m}, 2 \mathrm{H})$, 7.38-7.39 (m, $1 \mathrm{H}) ;{ }^{13} \mathrm{C} \mathrm{NMR}\left(\mathrm{CDCl}_{3}, 100 \mathrm{MHz}\right) \delta 119.2$, $122.8,123.5,125.8,125.9,127.3,135.1,138.6$.

4.4.18. 3-(4-Methoxyphenyl)thiophene. White solid. Mp 130-132 ${ }^{\circ} \mathrm{C}$ from EtOH (lit. $\left.{ }^{33} 127{ }^{\circ} \mathrm{C}\right) .{ }^{1} \mathrm{H} \mathrm{NMR}\left(\mathrm{CDCl}_{3}\right.$, $400 \mathrm{MHz}) \delta 3.83(\mathrm{~s}, 3 \mathrm{H}), 6.92(\mathrm{~d}, J=6.4 \mathrm{~Hz}, 2 \mathrm{H}), 7.32-$ $7.35(\mathrm{~m}, 3 \mathrm{H}), 7.51(\mathrm{~d}, J=6.4 \mathrm{~Hz}, 2 \mathrm{H}) ;{ }^{13} \mathrm{C} \mathrm{NMR}\left(\mathrm{CDCl}_{3}\right.$, $100 \mathrm{MHz}) \delta 55.5,113.9,118.6$ (2C), 125.7, 125.8, 127.1 (2C), 128.3, 141.5, 158.2. 
4.4.19. Diphenylmethane. Colourless liquid. ${ }^{34}{ }^{1} \mathrm{H}$ NMR $\left(\mathrm{CDCl}_{3}, 400 \mathrm{MHz}\right) \delta 4.11(\mathrm{~s}, 2 \mathrm{H}), 7.31-7.34(\mathrm{~m}, 6 \mathrm{H})$, 7.40-7.44 (m, 4H); ${ }^{13} \mathrm{C}$ NMR $\left(\mathrm{CDCl}_{3}, 100 \mathrm{MHz}\right) \delta 42.1$, 125.7 (2C), 128.0 (4C), 128.5 (4C), 140.6 (2C).

\section{Acknowledgements}

The research was financially supported by the National Science Council of Taiwan (NSC94-2113-M-027-002).

\section{References and notes}

1. (a) Metal-Catalyzed Cross-Coupling Reactions; Diederich, F., Stang, P. J., Eds.; Wiley-VCH: New York, NY, 1998; (b) Cross-Coupling Reactions: A Practical Guide; Miyaura, N., Ed.; Topics in Current Chemistry Series 219; Springer: New York, NY, 2002; (c) de Meijere, A.; Diederich, F. MetalCatalyzed Cross-Coupling Reactions, 2nd ed.; Wiley-VCH: Weinheim, 2004.

2. (a) Tamao, K.; Sumitani, K.; Kumada, M. J. Am. Chem. Soc. 1972, 94, 4374; (b) Corriu, R. J. P.; Masse, J. P. J. Chem. Soc., Chem. Commun. 1972, 144.

3. For recent reviews, see: (a) Tamao, K. J. Organomet. Chem. 2002, 653, 23; (b) Hillier, A. C.; Grasa, G. A.; Viciu, M. S.; Lee, H. M.; Yang, C.; Nolan, S. P. J. Organomet. Chem. 2002, 653, 69; (c) Anctil, E. J.-G.; Snieckus, V. J. Organomet. Chem. 2002, 653, 150; (d) Hermann, W. A.; Öfele, K.; Preysing, D. V.; Schneider, S. K. J. Organomet. Chem. 2003, 687, 229; (e) Schröter, S.; Stock, C.; Bach, T. Tetrahedron 2005, 61, 2245; (f) de Meijere, A.; Stulgies, B.; Albrecht, K.; Rauch, K.; Wegner, H. A.; Hopf, H.; Scott, L. T.; Eshdat, L.; Aprahamian, I.; Rabinovitz, M. Pure Appl. Chem. 2006, 78, 813.

4. Banno, T.; Hayakawa, Y.; Umeno, M. J. Organomet. Chem. 2002, 653, 288 .

5. (a) Lipshutz, B. H.; Tasler, S.; Chrisman, W.; Spliethoff, B.; Tesche, B. J. Org. Chem. 2003, 68, 1177; (b) Frieman, B. A.; Taft, B. R.; Lee, C.-T.; Butler, T.; Lipshutz, B. H. Synthesis 2005, 17, 2989.

6. (a) Styring, P.; Grindon, C.; Fisher, C. M. Catal. Lett. 2001, 77, 219; (b) Phan, N. T. S.; Brown, D. H.; Adams, H.; Spey, S. E.; Styring, P. Dalton. Trans. 2004, 1348.

7. Phan, N. T. S.; Brown, D. H.; Styring, P. Green Chem. 2004, 6, 526.

8. For reviews, see: (a) Corma, A. Chem. Rev. 1997, 97, 2373; (b) Thomas, J. M. Angew. Chem., Int. Ed. 1999, 38, 3588; (c) Ying, J. Y.; Mehnert, C. P.; Wong, M. S. Angew. Chem., Int. Ed. 1999, 38, 56; (d) Anwander, R. Chem. Mater. 2001, 13, 4419; (e) Biff, A.; Zecca, M.; Basato, M. J. Mol. Catal. A: Chem. 2001, 173, 249; (f) He, X.; Antonelli, D. Angew. Chem., Int. Ed. 2002, 41, 214; (g) De Vos, D. E.; Dams, M.; Sels, B. F.; Jacobs, P. A. Chem. Rev. 2002, 102, 3615; (h) Trong On, D.; DesplantierGiscard, D.; Danumah, C.; Kaliaguine, S. Appl. Catal. A: Gen. 2003, 253, 545; (i) Thomas, J. M.; Raja, R. J. Organomet. Chem. 2004, 689, 4110; (j) Li, C. Catal. Rev. 2004, 46, 419; (k) Taguchi, A.; Schüth, F. Microporous Mesoporous Mater. 2005, 77, 1; (l) Hoffmann, F.; Cornelius, M.; Morell, J.; Fröba, M. Angew. Chem., Int. Ed. 2006, 45, 3216.
9. (a) Mehnert, C. P.; Weaver, D. W.; Ying, J. Y. J. Am. Chem. Soc. 1998, 120, 12289; (b) Zhou, J.; Zhou, R.; Mo, L.; Zhao, S.; Zheng, X. J. Mol. Catal. A: Chem. 2002, 178, 289; (c) Yang, H.; Zhang, G.; Hong, X.; Zhu, Y. J. Mol. Catal. A: Chem. 2004, 210, 143; (d) Venkatesan, C.; Singh, A. P. J. Catal. 2004, 227, 148; (e) González-Arellano, C.; Corma, A.; Iglesias, M.; Sánchez, F. Adv. Synth. Catal. 2004, 346, 1758; (f) Tsai, F.-Y.; Wu, C.-L.; Mou, C.-Y.; Chao, M.-C.; Lin, H.-P.; Liu, S.-T. Tetrahedron Lett. 2004, 45, 7503.

10. Kosslick, H.; Mönnich, I.; Paetzold, E.; Fuhrmann, H.; Fricke, R.; Müller, D.; Oehme, G. Microporous Mesoporous Mater. 2001, 44-45, 537.

11. Mukhopadhyay, K.; Sarkar, B. R.; Chaudhari, R. V. J. Am. Chem. Soc. 2002, 124, 9692.

12. González-Arellano, C.; Corma, A.; Iglesias, M.; Sánchez, F. Catal. Today 2005, 107-108, 362.

13. Kantam, M. L.; Chowdari, N. S.; Rahman, A.; Choudary, B. M. Synlett 2005, 1413.

14. (a) Bandini, M.; Luque, R.; Budarin, V.; Macquarrie, D. J. Tetrahedron 2005, 61, 9860; (b) Cai, M.; Xu, Q.; Wang, P. J. Mol. Catal. A: Chem. 2006, 250, 199.

15. Djakovitch, L.; Dufaud, V.; Zaidi, R. Adv. Synth. Catal. 2006, $348,715$.

16. Clark, J. H.; Macquarrie, D. J.; Mubofu, E. B. Green Chem. 2000, 2, 53.

17. Lin, H.-P.; Tsai, C.-P. Chem. Lett. 2003, 32, 1092.

18. (a) Chouzier, S.; Gruber, M.; Djakovitch, L. J. Mol. Catal. A: Chem. 2004, 212, 43; (b) Rollet, P.; Kleist, W.; Dufaud, V.; Djakovitch, L. J. Mol. Catal. A: Chem. 2005, 241, 39.

19. (a) Oki, A. R.; Morgan, R. J. Synth. Commun. 1995, 25, 4093; (b) Will, G.; Boschloo, G.; Rao, S. N.; Fitzmaurice, D. J. Phys. Chem. B 1999, 103, 8067.

20. Doyle, J. R.; Slade, P. E.; Jonassen, H. B. Inorg. Synth. 1960, $6,218$.

21. Becht, J.-M.; Gissot, A.; Wagner, A.; Mioskowski, C. Chem.Eur. J. 2003, 9, 3209.

22. Milstein, D.; Stille, J. K. J. Am. Chem. Soc. 1979, 101, 4992.

23. Itoh, K.; Okazaki, K.; Chow, Y. L. Helv. Chim. Acta 2004, $87,292$.

24. Mowery, M. E.; DeShong, P. J. Org. Chem. 1999, 64, 1684.

25. Wynberg, H.; van Driel, H.; Kellogg, R. M.; Buter, J. J. Am. Chem. Soc. 1967, 89, 3487.

26. Denmark, S. E.; Ober, M. H. Org. Lett. 2003, 5, 1357.

27. Ohri, R. V.; Radosevich, A. T.; Hrovat, K. J.; Musich, C.; Huang, D.; Holman, T. R.; Toste, F. D. Org. Lett. 2005, 7, 2501.

28. Norman, R. O. C.; Thomas, C. B.; Willson, J. S. J. Chem. Soc., Perkin Trans. 1 1973, 325.

29. Korzeniowski, S. H.; Blum, L.; Gokel, G. W. Tetrahedron Lett. 1977, 22, 1871.

30. Tamura, Y.; Yoshimoto, Y.; Tada, S.-I.; Kunimoto, K.; Matsumura, S.; Murayama, M.; Shibata, Y.; Enomoto, H. J. Med. Chem. 1981, 24, 1006.

31. Wynberg, H.; Bantjes, A. J. Org. Chem. 1959, 24, 1421.

32. Botteghi, C.; Lardicci, L.; Menicagli, R. J. Org. Chem. 1973, 38, 2361.

33. Kirsch, G.; Prim, D. Synth. Commun. 1994, 24, 1721.

34. Eisch, J. J.; Dutta, S. Organometallics 2005, 24, 3355. 